\title{
MTMT: megújulás és lehetőségek
}

A Magyar Tudományos Mủvek Tárára (MTMT) a tudományos-könyvtári közösség általában mint szcientometriai adatbázisra tekint - mi most a tudományos bibliográfiák hosszú hagyományának folytatójaként mutatjuk be, megvizsgálva az adatbázisban rejlő lehetőségeket, sorba véve a kihívásokat, amelyekkel szembe kell nézzünk az új funkció kialakítása során.

Nem vállaljuk el a tudományos szakirodalmi bibliográfiák teljes történetének ismertetését, csak egyetlen tudomány - a csillagászat - területéről hozunk néhány példát. Friedrich Weidler Wittenbergben 1755ben kiadott Bibliographia Astronomica-ja ma is jó segédeszköze a régi csillagászati könyvek gyüjtőinek - hasonmás kiadásban is elérhető. A párizsi Observatoire igazgatója, Jerome Lalande 1803-ban adta ki a Bibliographie Astronomique-t, amit 1882 és 1889 között három kötetben kiadott Bibliographie General de L'Astronomie követett, J. C. Houzeau és A. Lancaster munkája. A XX. században a csillagászati bibliográfia készítése rendszeres tevékenységgé vált, Walter Wislicenus indította el az Astronomischer Jahresbericht-et a század elején ${ }^{1}$, ami 1969-tôl átadta helyét a J. Springer kiadásban megjelent, immár angol nyelvü Astronomy and Astrophysics Abstracts-nak. A mai - immár heti frissítéssel müködő, csak digitális formában létező - utód a NASA/SAO Astrophysics Data System $(\mathrm{ADS})^{2}$. Sokat mond a tudomány nemzetközi központjainak eltolódásáról, ha a bibliográfiák szerkesztőinek nemzetiségét, kiadásuk helyét megfigyeljük: Németország, Franciaország, ismét Németország végül az Amerikai Egyesült Államok. Amikor ezek a bibliográfiák megjelentek, elsősorban a tudományos kutatás eszközei voltak. Ma a Bibliographia Astronomica már inkább antikváriusoknak érdekes, Lalande bibliográfiáját és a „Houzeau-Lancaster” köteteit a tudománytörténészek forgathatják,

${ }^{1}$ Duerbeck, H. W.: Walter F. Wislicenus and Modern Astronomical Bibliography. = The Multinational History of Strasbourg Astronomical Observatory. Astrophysics and Space Science Library, Vol. 330. 2005. 153. p.

${ }^{2}$ Accomazzi, A. et al.: ADS: The Next Generation Search Platform. = Library and Information Services in Astronomy VII: Open Science at the frontiers of Librarianship. ASP Conference Series, Vol. 492. 2015. 189. p. 
az ADS pedig egyaránt szolgálja a kutatókat és azokat, akiknek az egyéni vagy intézményi kutatást értékelniük kell.

Az MTMT (most ideértve elődeit, a TPA-t és a KPA-t is) a rendszerváltás után átalakuló, nemzetközi megméretésre törekvő hazai tudományosság értékelési igényeinek kiszolgálására jött létre. Bibliográfiai szerepre nemigen törekedhetett mindmáig - a természettudósok számára a tudományos szakirodalomban való tájékozódáshoz nem sok segítséget adott a csupán hazai müveket tartalmazó rendszer, a bölcsészeknek pedig a mindössze néhány éves lefedettség volt elégtelen. A helyzet azonban mára megváltozott.

Egy TÁMOP projekt eredményeként az egyetemek publikációs tevékenysége 2007-ig visszamenőleg a rendszerbe került (az MTA intézményhálózata esetében ez a szinte teljes lefedettség már korábban megvolt, 1992-ig visszamenőleg). A 2015 nyarán módosított MTA törvény (valamint az azzal együtt módosított felsőoktatási törvény) eredményeként a jövőben minden állami támogatás felhasználásával született tudományos publikációt az MTMT rendszerében rögzíteni kell. Arról, hogy a hazai tudományos bibliográfia a következő évek publikációs tevékenységét teljesen lefedje, nem csupán a törvényi kötelezettség gondoskodik, hanem az is, hogy az MTMT adatait a finanszírozó hatóságok az értékeléshez felhasználják. Többé egyetlen állami finanszírozású intézmény sem engedheti meg magának, hogy publikációs tevékenysége hiányosan jelenjen meg az adatbázisban, és a szerzők sem építhetik tudományos karrierjüket anélkül, hogy publikációs és idézettségi adataik ne lennének itt nyilvántartva.

Egyre növekvő időbeli lefedettségével, a megjelenő publikációk egyre teljesebb körü nyilvántartásával az MTMT érdekessé válhat a „hazai” tudományok művelői számára, mint szakirodalmi tájékozódást szolgáló eszköz. Annál is inkább, mert az MTMT bibliográfiai rekordjai mellé bekerültek a múvek interneten elérhető teljes szövegü változataihoz elvezető ugrópontok, szembetủnően jelezve azt a tényezőt is, vajon szabadon, elöfizetés nélkül is elérhető-e az adott mü? Az MTMT szcientometriai funkciója biztosítja azt, hogy az adatbázis müködjön és lényegében minden mü oda bekerüljön. Most megjelenhet emellett a tájékoztató funkció is, bár ez kétségtelenül nem minden tudományterület kutatói számára lesz érdekes.

Mi kell ahhoz, hogy a tudományos tájékoztató, szakirodalmi kereső funkció jól müködhessen? A megfelelö lefedettség alapkövetelményén túl említettük már az MTMT-ben a publikációk teljes szövegü változataira mu- 
tató hiperhivatkozásokat, és az Open Access jelölést. Ahogy a nyílt hozzáférés terjed, ahogyan a hazai repozitóriumok száma gyarapszik, méretük növekszik, egyre több tartalom válik az MTMT-n keresztül elérhetővé - a Magyar Tudományos Mủvek Tára a hazai intézményi repozitóriumok tudományos tartalmainak közös keresőjeként, aggregátoraként müködhet. (A repozitóriumokban nem csupán tudományos tartalmak vannak, szükség van más közös keresőre is az MTMT mellett.)

Míg korábban azzal érveltünk, hogy a törvényi szabályozás és az érdekeltség biztosítja majd a teljes lefedettséget, el kell ismerjük, fontos szerepe lesz annak is, milyen terheket ró majd a kutatókra az adatfelvitel. Már amennyiben nekik kell az adatokat felvinniük. Nem feledkezhetünk meg az adatok minőségéről sem. A magyar tudományos bibliográfiának teljesnek és pontosnak kell lennie, naprakésznek valamint olcsónak. A felsorolt követelmények mindegyikét, akár közülük kettőt-kettőt, esetleg hármat is teljesíthetünk, de mindegyiket egyszerre? A megújuló MTMT-ben a szerzőkre - és bizonyos területeken adminisztrátoraikra - jutó terhelést csökkenteni szükséges. A szerzői vagy adminisztrátori adatfelvitel lehetősége megmarad, ez biztosítja majd a teljességet és a felelős ellenőrzést. Azonban a hazai kiadású müvek esetében a bibliográfiai adatokat egyre inkább a kiadóktól, szerkesztőségektől próbáljuk beszerezni. Az MTA Könyv- és Folyóirat-kiadó Bizottsága által támogatott folyóiratoknál vezettük be elöször ezt a gyakorlatot. Ahol lehet, a jövőben arra törekszünk majd, hogy az adatátvitel automatikus legyen. Mindazon kiadóknál, amelyek adatbázis-alapú szerkesztőségi és publikációs rendszerekkel müködnek, megoldható lesz ez. Gépi adatátvételre törekszünk mind az Akadémiai Kiadó által használt Atypon Literatum platformjából, mind a számos kis „,indie” tudományos folyóirat által használt Open Journal Systems szoftverből.

Említettük, hogy az MTA kutatóhálózatának adatai 1992-től szerepelnek a rendszerben - igény lenne a felsőoktatás adatait is teljessé tenni az 1990-es évek elejéig. Felmerült az MTMT adatainak szisztematikus bövítése még ennél is korábbi időpontokig. Tudományértékelési céllal csak az intézmények tekintetében lehet érdekes visszamenni további évtizedekre, az egyéni tudományos karrierek szempontjából az 1970-as éveknél korábbi időszak már nemigen lehet érdekes. Ám történeti oldalról nem csupán az intézményi bibliográfiák, hanem az egyéni tudósbibliográfiák is érdekesek lehetnek. Az MTA tagjainak bibliográfiáit akár az Akadémia 
alapításáig visszamenőleg fel lehetne vinni. Kérdés, hogy a szcientometriai felhasználhatóság lehetőségének csökkenésével, a tudománytörténeti-bibliográfiai hasznosítás céljával finanszírozható lesz-e az adatbázis hosszú időre visszanyúló kiterjesztése? Vajon létre tudjuk-e hozni id. Szinnyei József bibliográfiájának tudományos müvekre, kutatókra korlátozott modern változatát?

Elengedhetetlen az MTMT jelenlegi szoftverének, a MyCite-nak a lecserélése - szerencsére a 2015 augusztusában befejeződött TÁMOP projekt erre is lehetőséget adott. Sokkal könnyebben használható felület kell a tájékoztató funkció ellátásához. A MyCite2-nek lesz mobileszközökön is használható nyilvános felülete. Kihívást jelent az, hogy a könnyü használhatóság mellett a felület lehetőséget adjon az összetett feltételekkel történő kereséseknek, a találati listák több lépésben való szűkítésének. Az új nyilvános felület kétnyelvü is lesz. Bár az elsődleges célközönséget a hazai kutatók jelentik, az adatbázis kinyílik mind a külföldi kutatók, mind a hazai tudományszerető publikum előtt is.

Nem müködhet a tájékoztató funkció anélkül, hogy a publikációk tudományterületi besorolását el ne végeznénk. Ilyen jelenleg nincs az MTMT-ben, az egyes tudományterületek értékelési igényeinek különbsége csak az értékelő táblázatoknál - tehát az adatbázisból képzett öszszesítéseknél - jelenik meg. Kihívást jelent a megfelelö klasszifikációs séma kiválasztása - különböző tudományrendszertant használ a Web of Science, a Scopus vagy a Library of Congress, különböző az Ortelius vagy a Frascati Fields of Science besorolási rendszere, nem is beszélve a hazai magas szintü tudományterületi felosztásokról (ilyennek tekinthetjük az MTA osztályokra való tagozódását is). Ezek a rendszerek persze többé-kevésbé leképezhetők egymásra. Az MTMT-ben tárolt másfél millió közleményrekord tudományterületi besorolása jelenti a második kihívást. Folyóiratcikkeknél valószínűleg megoldható lesz a besorolás, amennyiben a folyóirat maga besorolható. A könyvek, könyvfejezetek, konferenciacikkek besorolását talán meg lehet kísérelni a szerzők vagy munkahelyeik besorolásával, de az adatbázisban jelenleg ehhez sem áll rendelkezésre megfelelő információ. Határterületeket tárgyaló cikkeknél alighanem csak a szerző tudja majd a besorolást megtenni, egy-egy cikkhez több tudományterület hozzárendelésével.

Felvetődik a kérdés, mi lehet a viszonya az MTMT-nek a hazai könyvtári közösség bibliográfiai projektjeihez? A különböző bibliográfiák gyüj- 
tőköre, céljai különbözőek, de nyilvánvaló kapcsolatok lehetnek. Itt csupán egy projektet említünk most meg: a MATARKA-t, amit az MTMT adminisztrátorai már régóta használnak. Az MTMT visszamenőleges bövítése esetén kínálkozik a MATARKA adatainak felhasználása. Az újonnan publikált hazai tudományos folyóiratcikkek tekintetében pedig talán majd a MATARKA vehet át adatokat az MTMT-ből.

Az MTMT nem csupán hazai vonatkozású publikációk leíró adatait tartalmazza, de az ezekre kapott idézeteket is. (A korábban említett csillagászati bibliográfiák közül a legújabb, az ADS is ilyen.) Az idézetek felhasználásával képet alkothatunk a publikációk hatásáról - ennek a szcientometriai jelentőségével most nem foglalkozunk. A citációs kapcsolatok viszont fontosak az eszmeáramlatok, a tudósok közötti kapcsolatok, kölcsönhatások tanulmányozása szempontjából is. Kopernikusz De revolutionibus-jának recepciótörténetét izgalmas nyomozómunkával lehetett felderíteni ${ }^{3}$ - az MTMT adatainak felhasználásával szinte folyamatosan követhető a tudományos felismerések terjedése, kollaborációk alakulása. (Az idézettségi hálózatok mellett kollaborációs hálózatok is felrajzolhatók, ezek feltérképezéséhez azonban szükséges a külföldi társszerzők azonosítása, intézményi affiliációik rögzítése.) Az idézési kapcsolatok felhasználhatók a tudományos szakirodalmi tájékoztatásban is: segítségükkel megtalálhatók az egy-egy tudományos téma müveléséhez nélkülözhetetlen alapmüvek, vagy éppen a területtel foglalkozó legjobb áttekintő cikkek - ezt a funkciót megvalósították az ADS-ben is.

A mi MTMT-nk szükségszerüen provinciális, a nemzetközi kitekintés, összehasonlítás céljára nem használható. Amíg a nemzeti tudományokban, a magyar nyelvü tudományos irodalomban teljes lefedettséget biztosíthat (amit a nagy külföldi adatbázisok nem tudnak és nem is akarnak, mert ami csak nekünk érdekes, azon nem tudnak eleget keresni), addig a nemzetközi tudományokban sohasem helyettesítheti majd a nagy kereskedelmi adatbázisokat. Ötvözve az intézményes adatimportot a szerzői beavatkozással, a szerzők és a hazai intézményrendszer pontos ismeretével, a kutatóhelyekkel együttmüködésben történő fejlesztéssel a Magyar Tudományos Mủvek Tára olyan adatbázissá válik, amelynél pontosabbat, teljesebbet a piacon beszerezni nem lehet.

${ }^{3}$ Farkas Gábor Farkas: A könyv, amelyet senki sem olvasott. Adalékok a heliocentrikus modellről folytatott vitához. Magyar Tudomány, 176. évf. 2015. 3. sz. 268-274. p. 


\section{Rezümé}

A Magyar Tudományos Művek Tára a nemzeti tudományos bibliográfiai adatbázis az MTA törvény szerint. Elsődleges - és mindezidáig kizárólagos - feladata adatokat szolgáltatni az egyéni és intézményi tudományos teljesítmény méréséhez. Mivel egyre tágabb idöhatárok között rendelkezik teljes lefedettséggel, újabb alkalmazása lehet: a „hazai” tudományok tekintetében szolgálhatja a szakmai tájékoztatást, szakirodalom-keresést.

\section{MTMT: renewal and prospects}

The Database of Hungarian Scholarly Works (Magyar Tudományos Mủvek Tára, MTMT) gains new applications. Besides supplying statistics for scientometrics it is becoming a scholarly literature discovery tool - at least for disciplines publishing in Hungarian, on Hungarian-related subjects.

HOLL ANDRÁS

informatikai főigazgató-helyettes

MTA KIK 